\title{
Insulin-Like Growth Factor 1 Receptor Beta Chain
}

National Cancer Institute

\section{Source}

National Cancer Institute. Insulin-Like Growth Factor 1 Receptor Beta Chain. NCI

Thesaurus. Code C120492.

Insulin-like growth factor 1 receptor beta chain (627 aa, 71 kDa) is encoded by the human IGF1R gene. This protein plays a role in growth factor-mediated receptor tyrosine kinase activity. 